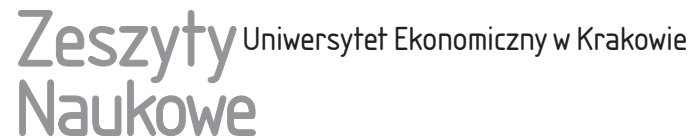

\author{
Marcin Kędzior \\ Konrad Grabiński
}

\section{Forma prezentacji informacji w sprawozdaniach finansowych a ich użyteczność - przegląd wybranych badań}

\section{Streszczenie}

Celem artykułu jest przedstawienie wskazywanych w literaturze przedmiotu argumentów dotyczących wpływu sposobu prezentacji sprawozdań finansowych na ich użyteczność. Podstawową metodą badawczą zastosowaną w opracowaniu jest analiza krajowej i zagranicznej literatury przedmiotu oraz prezentowanych w niej badań empirycznych innych autorów. W większości przypadków badania i opinie, które są przedmiotem analizy, odnoszą się do sposobów prezentacji sprawozdania finansowego wymaganych przez polską ustawę o rachunkowości, MSR/MSSF oraz US GAAP. Jako jeden z istotnych obszarów formy prezentacji wyróżniono m.in. poziom agregacji i dezagregacji informacji sprawozdawczej. Kolejnym aspektem formy prezentacji przedstawionym w artykule są założenia projektu standardu opracowanego wspólnie przez Radę Międzynarodowych Standardów Rachunkowości (IASB) i Radę Standardów Rachunkowości Finansowej (FASB), dotyczącego ujednolicenia prezentacji poszczególnych części sprawozdania finansowego i jego potencjalne oddziaływanie na użyteczność tego sprawozdania. Analiza wyników badań innych autorów oraz opinii dostarcza argumentów potwierdzających główną tezę, że forma prezentacji ma wpływ na użyteczność sprawozdania finansowego.

Marcin Kędzior, Uniwersytet Ekonomiczny w Krakowie, Wydział Finansów i Prawa, Katedra Rachunkowości Finansowej, ul. Rakowicka 27, 31-510 Kraków, e-mail: kedziorm@uek.krakow.pl

Konrad Grabiński, Uniwersytet Ekonomiczny w Krakowie, Wydział Finansów i Prawa, Katedra Rachunkowości Finansowej, ul. Rakowicka 27, 31-510 Kraków, e-mail: kg@uek.krakow.pl 
Słowa kluczowe: użyteczność sprawozdania finansowego, forma prezentacji sprawozdań finansowych, agregacja i dezagregacja elementów sprawozdań finansowych, założenia koncepcyjne sprawozdawczości finansowej.

Klasyfikacja JEL: M41, O16.

\section{Wprowadzenie}

Głównym problemem przedstawionym w opracowaniu jest wpływ formy prezentacji na użyteczność sprawozdania finansowego. W każdym systemie normatywnym sprawozdawczości finansowej oraz środowisku, w którym funkcjonują użytkownicy sprawozdań finansowych, wymagania dotyczące formy prezentacji mogą mieć wpływ na użyteczność raportowanej informacji. Przedstawione rozważania dotyczą formy prezentacji sprawozdań finansowych sporządzonych zgodnie z MSSR/MSSF oraz w nieco mniejszym stopniu sporządzonych według ustawy o rachunkowości oraz US GAAP. Głównym celem sprawozdań finansowych, zgodnie z „Założeniami koncepcyjnymi sprawozdawczości finansowej” opracowanymi przez Radę Międzynarodowych Standardów Rachunkowości (IASB - International Accounting Standards Board), jest dostarczanie użytecznej informacji finansowej dla użytkowników, którzy są obecnymi i potencjalnymi dostarczycielami kapitału do jednostki (Międzynarodowe Standardy Sprawozdawczości Finansowej 2011), podobnie uważają (Andrzejewski i Maślanka 2016, Maślanka 2004). E. Łazarowicz (2016, s. 90-92) przedstawia dogłębną analizę struktury celów współczesnej sprawozdawczości finansowej. Autorka wskazuje na decyzyjny charakter użyteczności, który jest uzależniony od tego, kto jest odbiorcą informacji finansowej, co dotyczy w szczególności decyzji podejmowanych przez takie podmioty, które dostarczają kapitał do jednostki lub mogą potencjalnie go dostarczać. Do tej grupy zostali zaliczeni inwestorzy, pożyczkodawcy i inni wierzyciele, a informacja użyteczna jest definiowana jako taka, która wspomaga ich w decyzjach dotyczących zakupu, sprzedaży lub utrzymania instrumentów kapitałowych i dłużnych.

W założeniach koncepcyjnych przedstawione zostały również cechy jakościowe w formie postulatów wskazujących, czym powinna się odznaczać użyteczna informacja finansowa. W szczególności w założeniach koncepcyjnych sprawozdawczości finansowej (Międzynarodowe Standardy Sprawozdawczości Finansowej 2011, CJ19) wskazuje się, że porównywalność, sprawdzalność, terminowość i zrozumiałość to cechy, które wpływają na poprawę użyteczności sprawozdań finansowych. $Z$ punktu widzenia analizowanego problemu należy stwierdzić, że poprawa formy prezentacji w szczególności powinna wpłynąć na takie cechy jakościowe, jak porównywalność oraz zrozumiałość sprawozdania finansowego, a przez to pośrednio podwyższać użyteczność sprawozdań finansowych. 
Jednym z czynników, które mogą wpływać na jakość sprawozdań finansowych, jest forma prezentacji informacji w sprawozdaniu. Sposób prezentacji sprawozdań finansowych jest przedmiotem licznych badań empirycznych. W polskiej literaturze przedmiotu do istotnych prac odnoszących się do formy prezentacji sprawozdania finansowego należy zaliczyć m.in. prace H. Buk (2011), K. Czubakowskiej (1989), K. Winiarskiej (1994), J. Gierusza (2005, 2010), E. Walińskiej (2009, 2010), P. Wójtowicza (2009), A. Górskiej i A. Parkitnej (2010), K. Zasiewskiej (2011), K. Grabińskiego (2012) oraz B. Bek-Gaik (2013). Przedmiotem analiz powyższych badań jest na ogół sposób prezentacji podstawowych części sprawozdania finansowego bilansu lub rachunku zysków i strat.

Dla potrzeb rozważań prowadzonych w niniejszym artykule formę prezentacji zdefiniowano jako wymagany przez normy prawne rachunkowości układ treści prezentowanych w zasadniczej części sprawozdania finansowego, wymagany poziom szczegółowości, jak również związki pomiędzy poszczególnymi elementami. Przez zasadniczą część sprawozdania finansowego autorzy rozumieją bilans (sprawozdanie z sytuacji finansowej), rachunek wyników (sprawozdanie z całkowitych dochodów), zestawienie zmian w kapitale własnym oraz sprawozdanie z przepływów pieniężnych. Forma prezentacji dotyczy również informacji dodatkowej, jednak w większości badań empirycznych i normatywnych nie jest ona przedmiotem badań.

Ponieważ rozważania przedstawione w artykule dotyczą głównie regulacji MSR/MSSF, istotne jest również zdefiniowanie pojęć pozycji, składników oraz elementów sprawozdania finansowego. W regulacjach MSR/MSSF nie ma podanych bezpośrednich definicji tych pojęć (również w słowniku MSR/MSSF) i panuje w tym zakresie chaos pojęciowy. Z analizy treści MSR 1 „Prezentacja sprawozdań finansowych" (WP 07, WP 12, WP 13) można wywnioskować, że przez pojęcie pozycji sprawozdania finansowego można rozumieć każdy rodzaj informacji, która jest wykazywana odrębnie w sprawozdaniu finansowym i do której jest przypisana wartość liczbowa. Co więcej, w MSR 1 (par. 7) stwierdza się, że informacja dodatkowa zawiera również informacje na temat, ,pozycji, które nie kwalifikują się do ujęcia”, czyli nie można ich uznać za składnik aktywów, zobowiązań itd., a ponadto jeżeli dana pozycja nie jest istotna, to można ją łączyć z innymi. Niektóre z zaprezentowanych w sprawozdaniu finansowym pozycji są dzielone na części składowe - kategorie i podkategorie, przykładowo rezerwy dzieli się na rezerwy z tytułu świadczeń pracowniczych i pozostałe rezerwy. Ponadto MSR 1 wymaga, aby w odniesieniu do każdej pozycji zaprezentowanej w zasadniczej części sprawozdania finansowego jednostka przedstawiła informacje uzupełniające w notach.

Jeżeli w wyniku stosowania zasady memoriałowej jednostka ujmuje pozycje, które spełniają kryteria ujmowania, to wtedy rozpoznawane pozycje są określane 
jako elementy sprawozdań finansowych: aktywa, zobowiązania, kapitał własny, dochody i zobowiązania (MSR 1, par. 28). Oprócz pojęć pozycji i elementów w MSR 1 stosuje się również pojęcie składników w odniesieniu do pozycji sprawozdania z całkowitych dochodów i pozycji kapitałów własnych. Pojęcia pozycji, składników oraz elementów są w literaturze często stosowane zamiennie, a rozróżnienie powyższych pojęć nie zostało jak dotąd uporządkowane od strony regulacyjnej. Z przedstawionej analizy wynika, że pojęcie pozycji jest najszersze i obejmuje swoim zakresem zarówno elementy, jak i składniki sprawozdania finansowego. W rezultacie można uznać, że w niniejszym artykule autorzy przez pojęcie pozycji rozumieją zagregowany opis rachunkowy spójnego pod względem treści zjawiska ekonomicznego, do którego została przypisana wartość liczbowa wyrażona w mierniku pieniężnym i która jest prezentowana w sprawozdaniu finansowym. Z kolei te pozycje, które spełniają kryteria uznawania i są ujmowane w bilansie lub sprawozdaniu z całkowitych dochodów, są określone mianem elementów. Pozostałe pozycje, które są wykazywane w sprawozdaniu z przepływów pieniężnych, czy też w zestawieniu zmian w kapitale własnym, autorzy proponują określać mianem składników sprawozdania finansowego.

Istotnym aspektem formy prezentacji jest poziom agregacji pozycji sprawozdania finansowego, czyli na jakim poziomie szczegółowości informacja powinna być prezentowana. Kolejny aspekt dotyczy układu i zawartości sprawozdań finansowych. W MSR 1 dopuszcza się tutaj daleko idącą dowolność, wskazano jedynie listę pozycji, które muszą być zaprezentowane w sprawozdaniu finansowym, podczas gdy polski ustawodawca w załącznikach do ustawy o rachunkowości rekomenduje konkretne rozwiązania w tym zakresie, które potocznie są określane jako wzorcowe sprawozdania finansowe. Przykładowo, w załączniku nr 1 przedstawiono zakres informacji wykazywanych w sprawozdaniu finansowym dla jednostek innych niż banki, zakłady ubezpieczeń i zakłady reasekuracji, a także wzór bilansu, rachunku zysków i strat itd. W rezultacie sprawozdania finansowe sporządzone według polskiej ustawy cechują się wyższym poziomem porównywalności pod względem formy prezentacji (Grabiński i Kędzior 2007). Należy jednak podkreślić, że zarówno w rozwiązaniach krajowych, jak i międzynarodowych brakuje spójności w zakresie budowy poszczególnych elementów sprawozdania finansowego.

W badaniach empirycznych nad formą prezentacji sprawozdań finansowych można zauważyć dwa ścierające się poglądy. Zwolennicy pierwszego argumentują, że przy założeniu silnej efektywności informacyjnej rynków kapitałowych miejsce i forma prezentacji sprawozdań finansowych nie powinny mieć znaczenia (Bratten, Choudhary i Schipper 2013). Podejście to zakłada, że użytkownicy mając dostęp do wiarygodnej informacji, są w stanie samodzielnie pozyskać i przetworzyć 
informacje do postaci przez nich pożądanej. W związku z tym organy stanowiące regulacje rachunkowości powinny jedynie zadbać o to, aby wiarygodna informacja znalazła się w sprawozdaniu finansowym, niezależnie od miejsca i formy jej prezentacji. Druga koncepcja zakłada odmienne stanowisko - wskazuje się, że sposób prezentacji ma istotne znaczenie dla zrozumienia przez użytkowników raportowanej informacji. W szczególności, problem badawczy jest formułowany następująco: czy rynek kapitałowy w inny sposób przetwarza informację ujętą w sprawozdaniu finansowym, tj. w bilansie i rachunku wyników, niż tę, która jest ujawniona w informacji dodatkowej. Przedstawiciele drugiego obozu wskazują na wyższe koszty przetwarzania informacji zaprezentowanej w informacji dodatkowej w stosunku do tej ujętej w bilansie i rachunku wyników (Davis-Friday i in. 1999; Ahmed, Kilic i Lobo 2006; Barth, Clinch i Shibano 2003) oraz postrzeganie przez użytkowników informacji dodatkowej jako mniej wiarygodnej (Choi, Collins i Johnson 1997, Davis-Friday, Liu i Mittelstaedt 2004, Choudhary 2011). Również D.E. Hirst i P.E. Hopkins (1998, s. 48) stwierdzają, że informacja nie będzie użyteczna, jeśli jednocześnie nie będzie dostępna oraz łatwa do przetworzenia (przejrzysta). W rezultacie można stwierdzić, że w literaturze przedmiotu są przedstawiane liczne argumenty wskazujące, że forma prezentacji i jasność przekazu ma istotne znaczenie dla użyteczności sprawozdań finansowych.

Celem opracowania jest próba oceny wpływu sposobu prezentacji informacji w sprawozdaniach finansowych na ich użyteczność. Głównym wnioskiem płynącym z prezentowanych rozważań jest wskazanie na konieczność opracowania przez organy stanowiące regulacje rachunkowości optymalnej formy prezentacji z punktu widzenia użyteczności sprawozdań finansowych. Podstawową metodą badawczą są badania literaturowe. W kolejnych punktach opracowania omówiono problemy agregacji i prezentacji informacji w sprawozdaniu finansowym oraz projekt standardu dotyczący nowej formy prezentacji.

Artykuł stanowi jedną z nielicznych w literaturze polskiej prób oceny wpływu formy prezentacji informacji w sprawozdaniu finansowym na jego użyteczność w kontekście propozycji standardu prezentacji sprawozdania finansowego opracowanego wspólnie przez IASB i Radę Standardów Rachunkowości Finansowej (FASB - Financial Accounting Standards Board). Zdaniem autorów powyższa koncepcja jest nadal atrakcyjną propozycją kierunku zmian sprawozdawczości finansowej. W dalszej części artykułu zostały przedstawione problemy dotyczące poziomu agregacji informacji prezentowanej w sprawozdaniu finansowym, harmonizacji rachunkowości w kontekście proponowanego wspólnego standardu IASB i FASB dotyczącego formy prezentacji i jego oceny oraz podsumowania i wnioski. 


\section{Poziom agregacji informacji prezentowanej w sprawozdaniu finansowym}

W przypadku bardziej skomplikowanych pozycji sprawozdawczych w zakresie ujęcia, wyceny i ewidencji istotne znacznie ma, na jakim poziomie szczegółowości jest przedstawiana informacja. Do elementów prezentowanych w sprawozdaniu finansowym, które odznaczają się dużym stopniem skomplikowania, zaliczane są m.in. takie pozycje, jak: świadczenia pracownicze, rezerwy na świadczenia emerytalne, instrumenty finansowe, czy też transakcje leasingu. Jak stwierdzają C. Wiedman i H. Wier (2004), dotyczy to zwłaszcza zagadnień, które uznawane są za kontrowersyjne i są regulowane poprzez obszerne standardy. W swoich badaniach empirycznych stawiają oni następujące pytanie: czy z punktu widzenia użyteczności decyzyjnej bardziej korzystna jest forma prezentacji jednej, syntetycznej pozycji, czy też korzystniejsza będzie forma prezentacji polegająca na rozbiciu tej pozycji na bardziej szczegółowe składniki oraz ich prezentacja w różnych miejscach sprawozdania finansowego?

B. Lev (1968, s. 247) wskazuje, że proces sprawozdawczości finansowej można postrzegać jako łączenie, lub inaczej agregację, szczegółowych informacji - kwot sald poszczególnych kont księgowych - w zbiorcze pozycje sprawozdawcze. Ponadto dodaje, że w założeniu użytkownik sprawozdania finansowego preferuje informacje bardziej szczegółowe niż zbiorcze, co oznacza, że poprzez proces agregacji następuje częściowa utrata wartości informacyjnej sprawozdania finansowego.

Proces odwrotny do agregacji informacji księgowej jest określany mianem dezagregacji i polega na rozłożeniu zbiorczej pozycji sprawozdawczej na elementarne części składowe. Ponadto dezagregacja pozwala na badanie, jak poszczególne składniki pozycji sprawozdawczej są związane z sytuacją makroekonomiczną lub wpływają na sytuację finansową jednostki sprawozdawczej i jej rentowność. Co jednak najważniejsze, proces rozbicia, przynajmniej w założeniu, powinien prowadzić do lepszego zrozumienia istoty zdarzenia czy transakcji, która jest opisywana w sprawozdaniu za pomocą danej pozycji sprawozdawczej, a zatem powinien korzystnie wpływać na użyteczność sprawozdań finansowych (Goncharov i Hodgson 2011).

Powyższe postulaty są zasadne, ponieważ sprawozdawczość w obecnym kształcie nie jest w stanie przekazać faktycznie użytecznych informacji dla różnych uczestników życia gospodarczego. Dotyczy to szczególnie inwestorów, którzy oczekują właściwych informacji o ryzyku i przyszłej stopie zwrotu (Pounder 2008, s. 20; Masztalerz 2010; Luty 2010). Dezagregacja pozycji może przynajmniej częśsiowo zmienić tę niekorzystną dla nich sytuację. Należy ponadto zwrócić uwagę, że sposób agregacji pozycji nie był przedmiotem zmian 
od lat 90. XX w. W opinii wielu osób nie jest on właściwy z punktu widzenia współcześnie funkcjonujących rynków kapitałowych i nie przekazuje wystarczająco szczegółowych informacji (DiFabio 2009, s. 45). Dezagregację pozycji popiera również Europejska Grupa Doradcza ds. Sprawozdawczości Finansowej (EFRAG - European Financial Reporting Advisory Group). Eksperci EFRAG wręcz uważają, że dezagregacja pozycji może stanowić jedną z najważniejszych zasad prezentacji sprawozdania finansowego. Dezagregacja pozycji sprawozdawczej ma również swoich przeciwników, którzy twierdzą, że dostarczanie zbyt szczegółowych informacji nie zwiększa użyteczności sprawozdań finansowych. Powołują się oni na zasadę istotności, zgodnie z którą każda informacja, która nie jest istotna, nie powinna być oddzielnie prezentowana w sprawozdaniu finansowym, a raczej należy ją wykazywać łącznie w zbiorczej pozycji sprawozdawczej. Ponadto wskazują, że sprawozdanie finansowe już obecnie przekazuje zbyt szczegółowe informacje, a użytkownik nie jest w stanie ich przetworzyć. Jest to widoczne m.in. w bardzo obszernych raportach rocznych liczących po kilkaset stron. Zbyt duża liczba szczegółowych informacji może utrudniać właściwą ocenę sytuacji finansowej jednostki, a także zebranie naprawdę istotnych danych. Dotyczy to głównie oceny płynności i elastyczności finansowej, bardzo istotnej dla inwestorów giełdowych. W przpadku dużej liczby pozycji sprawozdawczych w szczególności inwestorzy indywidualni mogą mieć problemy z analizą i interpretacją danych (Giacomino i Akers 2010, s. 61).

W opinii ekspertów EFRAG również natłok informacji w sprawozdawczości finansowej jest zjawiskiem niepożądanym, ponieważ utrudnia komunikację między poszczególnymi użytkownikami sprawozdawczości finansowej a jednostką gospodarczą (Prezentacja sprawozdań finansowych ... 2010). Badania w tym zakresie przeprowadzili L. Ragland i J.L. Reck (2016). Autorzy ci analizowali wpływ dezagregacji skomplikowanych pozycji sprawozdawczych na osąd użytkowników sprawozdań finansowych zaliczanych do tzw. nieprofesjonalnych inwestorów. Za pomocą eksperymentu na próbie 114 osób wykazali, że metoda prezentacji skomplikowanej pozycji sprawozdawczej - poziom agregacji - wpływa na ocenę tej pozycji przez użytkowników. W szczególności stwierdzili oni wyższy poziom zrozumienia tej pozycji przez użytkowników w przypadku jej dezagregacji na części składowe i ich prezentację w różnych częściach sprawozdania finansowego, tj. w bilansie i rachunku wyników. Wyniki badań mogą mieć istotne znaczenie dla mniej rozwiniętych rynków kapitałowych, na których poziom profesjonalizacji inwestorów jest znacząco niższy niż na rynkach bardziej rozwiniętych.

W regulacjach z zakresu rachunkowości problem agregacji zazwyczaj rozstrzygany jest przez odwołanie się do kryterium istotności. Należy ocenić bowiem, na ile istotna jest informacja dotycząca części pozycji sprawozdawczej. Jeżeli nie jest istotna, pozycja ta powinna być włączona do pozycji zbiorczej. Jednocześnie 
przepisy księgowe nie dostarczają ilościowych wytycznych w zakresie istotności, odwołując się w tym miejscu do profesjonalnego osądu księgowego. Wyniki badań empirycznych wskazują jednak, że w przypadku bardziej skomplikowanych pozycji sprawozdawczych ich rozłożenie na prostsze elementy i prezentacja w różnych częściach sprawozdania finansowego może korzystnie wpłynąć na użyteczność sprawozdań finansowych (Wiedman i Wier 2004). Konieczność podziału skomplikowanych pozycji sprawozdawczych powinna być jednak skodyfikowana w normach prawnych dotyczących rachunkowości. Nie ma w tej kwestii zgodności w literaturze przedmiotu. Konieczne jest bez wątpienia przeprowadzenie stosownych badań empirycznych (Acton 2009).

\section{Harmonizacja rachunkowości a nowy standard prezentacji sprawozdania finansowego}

Drugi aspekt formy prezentacji dotyczy rewolucyjnej zmiany sprawozdawczości finansowej, która kilka lat temu była szeroko dyskutowana na forum publicznym. Nie doczekała się ona realizacji w postaci regulacji prawnych i wprowadzenia w życie. Propozycja ta została sformułowana w okresie 2008-2010, kiedy współpraca między IASB i FASB była ciągle żywa, a wspólny projekt obu rad w zakresie nowej prezentacji sprawozdania finansowego uznawano za przyszłość procesu pełnej konwergencji i bardzo ważny krok w celu harmonizacji światowej rachunkowości.

Od czasu zawartych w 2004 r. porozumień w Norwalk podjęto liczne inicjatywy harmonizujące zróżnicowane przepisy krajowe rachunkowości, podkreślić jednak należy, że wspomniana inicjatywa IASB i FASB miała tutaj kluczowe znaczenie. W opinii wielu zainteresowanych stron było i jest nadal konieczne stworzenie globalnych standardów rachunkowości. Osiągnięcie tego celu utrudniać mogą różnice zdań w różnorodnych kwestiach między IASB i FASB, które ostatecznie doprowadziły do fiaska procesu konwergencji oraz braku realizacji m.in. omawianej koncepcji nowej formy prezentacji sprawozdań finansowych.

Rozpatrując stosowalność MSSF i US GAAP na świecie, te pierwsze standardy wydają się znacznie bardziej rozpowszechnione, a także w większym stopniu akceptowalne przez różnych użytkowników sprawozdań finansowych (Rivera i in. 2014). Obecnie szacuje się, że ponad 110 krajów na świecie deklaruje przyjęcie do stosowania MSSF. Z drugiej strony amerykański rynek kapitałowy nadal uważany jest za największy i najbardziej atrakcyjny na świecie, co znacząco wpływa na popularność US GAAP.

R. Herz, przewodniczący FASB w latach 2002-2013, pozytywnie oceniał inicjatywy zmierzające do ujednolicenia formatu sprawozdania finansowego 
w przekroju międzynarodowym (www.fasb.org/cs/BlobServer?blobcol=urldata\&blobtable $=$ MungoBlobs\&blobkey $=$ id\&blobwhere $=1175818337471 \&$, data dostępu: styczeń 2018). W tamtym czasie w praktyce gospodarczej występowała duża swoboda w zakresie prezentacji sprawozdania finansowego, w szczególności przygotowanego na podstawie wytycznych zawartych w MSSF, co ma miejsce również obecnie. W opinii R. Herza głównym celem standardu miała być poprawa użyteczności informacji i zwiększenie ich porównywalności na rynkach kapitałowych (zob. Cain 2008, s. 14). Wydaje się, że właśnie ten ostatni postulat miał faktycznie zdecydowany priorytet. Podobnie uważa K. Oliver (2014). Celem projektu było stworzenie wewnętrznie spójnych, światowych standardów rachunkowości zwiększających porównywalność i zrozumiałość sprawozdań finansowych. Cel ten wyklucza tworzenie dwóch niezależnych zestawów standardów rachunkowości, które są w dużym stopniu ze sobą porównywalne.

Stworzenie globalnych standardów rachunkowości ukierunkowanych na wspólną formę prezentacji, klasyfikacji, agregacji pozycji wykazywanych w sprawozdaniu finansowym jest bez wątpienia pożądane z perspektywy jakości sprawozdań finansowych. Niemniej nie istnieją na świecie badania, które jednoznacznie określają zarówno korzyści, jak i koszty harmonizacji rachunkowości (Ward, Ward i Deck 2012). Dominuje przekonanie o przewadze tych pierwszych nad drugimi. Postulowany w tamtym czasie, tj. w latach 2008-2010, nowy format prezentacji informacji nadal ma wiele zalet, tym bardziej że jak wskazuje T. Wójtowicz (2015), istnienie wielu opcji ujmowania i prezentacji danych finansowych powoduje, że użyteczność decyzyjna sprawozdania finansowego w dotychczasowej formie prezentacji jest niewielka.

Wspólne przedsięwzięcie IASB i FASB nie mogło stanowić zaskoczenia, ponieważ w MSR 1 oraz w rozwiązaniach opartych na US GAAP w zakresie prezentacji sprawozdania finansowego występowało i nadal występuje dużo podobieństw. Najważniejsze różnice dotyczą wybranych zagadnień odnoszących się do sprawozdania z sytuacji finansowej, prezentacji długoterminowego zadłużenia oraz aktywów z tytułu odroczonego podatku dochodowego. Większość różnic należy uznać za niewielkie, istotne w ograniczonym zakresie. Nowy standard dotyczący formy prezentacji mógł znacząco zwiększyć porównywalność sprawozdan finansowych sporządzonych według US GAAP i MSSF. Projekt nie eliminował wszystkich zastrzeżeń, jakie wnosiły obie strony, część założeń projektu zyskała aprobatę i akceptację zarówno IASB, jak i FASB (Oliver 2014).

Dla amerykańskich podmiotów, w szczególności działających w skali międzynarodowej, korzystna byłaby dalsza współpraca IASB i FASB. Zagraniczne oddziały amerykańskich koncernów są bardzo często zobligowane do sporządzania lokalnych sprawozdań finansowych w oparciu o MSSF (Rivera i in. 2014). P. Pacter $(2013$, s. 1) uważa, że dla wielu amerykańskich przedsiębiorstw, szcze- 
gólnie giełdowych, dobrym rozwiązaniem byłoby stworzenie jednego globalnego zestawu standardów rachunkowości. S.P. Ward, D.R. Ward i A.B. Deck (2012) podkreślają również potrzebę harmonizacji amerykańskich standardów rachunkowości z rozwiązaniami opartymi na MSSF. Ich dotychczasowa użyteczność na potrzeby podejmowania decyzji, a także stopień skomplikowania były poddane uzasadnionej krytyce. Powiązania między poszczególnymi częściami sprawozdawczości finansowej były również oceniane jako niejednoznaczne, szczególnie dla niedoświadczonego użytkownika sprawozdań finansowych. Dotyczy to zarówno regulacji MSSF, jak i US GAAP.

\section{Ocena propozycji standardu dotyczącego nowej formy prezentacji}

Nowa forma prezentacji sprawozdań finansowych stanowiła zasadniczą zmianę układu i koncepcji sprawozdania finansowego. W projekcie standardu zmianie poddano prezentację sytuacji finansowej, wyników z działalności czy sprawozdania z przepływów pieniężnych. Nowa wersja prezentacji sprawozdania finansowego przedstawia spójny i jednolity obraz działalności finansowej podmiotu gospodarczego (Prezentacja sprawozdań finansowych... 2010, s. 1). Części sprawozdania finansowego uzupełniają się wzajemnie, duża spójność występuje również na poziomie poszczególnych kategorii. Nowa forma prezentacji mogłaby ułatwić użytkownikom zaobserwowanie i zrozumienie relacji miedzy głównymi obszarami działalności biznesowej. Dezagregacja pozycji była konieczna i została przeprowadzona na podstawie kryterium funkcji, natury, podstawy wyceny z uwzględnieniem płynności i elastyczności finansowej. Podział pozycji sprawozdawczych miał na celu przekazanie bardziej użytecznych informacji (Ward i Ward 2013).

Informacje prezentowane w poszczególnych częściach sprawozdania finansowego zostały ujednolicone. Zarzutem czynionym tej propozycji był wysoki koszt przygotowania, analizy i interpretacji sprawozdania finansowego sporządzonego według nowych zasad. Trudno z drugiej strony zgodzić się z poglądem, że są to zmiany na tyle rewolucyjne, iż uniemożliwią właściwą ocenę podmiotu gospodarczego. Sprawozdanie sporządzone według nowej formuły wygląda na bardziej skomplikowane, ale w praktyce pogląd taki nie do końca jest uzasadniony (Ward i Ward 2013). Ze względu na konieczność przygotowania sprawozdania zgodnie z nowym formatem mógłby nastąpić wzrost zapotrzebowania na kursy, szkolenia, opracowania książkowe z omawianego zakresu, szczególnie wśród inwestorów indywidualnych.

We wspólnym projekcie standardu IASB i FASB zostały zaproponowane daleko idące zmiany w sprawozdawczości finansowej jednostek gospodarczych. 
Część autorów sygnalizowało pozytywną ich ocenę, inni negatywną, czy też zdecydowanie negatywną - według nich wprowadzenie takich zmian może powodować wręcz pogorszenie użyteczności sprawozdań finansowych w nowym formacie. Zarówno użytkownicy, jak i osoby przygotowujące sprawozdania finansowe niektóre zmiany popierają, podczas gdy inni są im przeciwni. Różnorodne wyniki badań są dostarczane na potrzeby IASB i FASB (Ward, Ward i Deck 2012). Przykładowo G. McClain i A.J. McLelland (2008) uważają, że nowa forma prezentacji sprawozdania finansowego mogłaby umożliwić lepszą ocenę przyszłych przepływów pieniężnych (Walińska 2010). Z kolei E. Henry i O.J. Holzmann (2008) podkreślają, że formy prezentacji sprawozdania finansowego nie powinny wywierać wpływu na decyzje użytkowników sprawozdania (DiFabio 2009, s. 44-47). Autorzy przywołują wyniki badań, które wskazują ograniczony, lecz istotny wpływ sposobu prezentacji danych na ocenę sytuacji finansowej firmy i przyszłe decyzje inwestycyjne. Informacja finansowa może być różnorodnie prezentowana w sprawozdaniu finansowym, a miejsce jej ujawnienia ma wpływ na decyzje finansowe interesariuszy.

W opinii A. Lennarda podstawowym celem nowej formy prezentacji sprawozdania finansowego było zwiększenie jego użyteczności (Lennard 2007). Autor ten uważa, że nie powinien to być jedyny cel zmian. Na uwagę zasługuje również potrzeba rozliczenia zarządu ze sprawowanych przez niego funkcji. Funkcja kontrolna nie stoi w końcu w sprzeczności z funkcją informacyjną sprawozdania finansowego. Nie można zapominać również o tym, że informacja użyteczna to także informacja, która jest wiarygodna. Autor krytykuje niedostateczne powiązanie nowej formy prezentowania sprawozdania finansowego z założeniami koncepcyjnymi rachunkowości.

Analizy ekspertów powołanych przez IASB zawierają zarówno pozytywne, jak i krytyczne oceny dotycząc omawianego standardu (Giacomino i Akers 2010). Zwrócono m.in. uwagę na zwiększenie poziomu spójności pomiędzy poszczególnymi częściami sprawozdania finansowego, ale także na nieprecyzyjną definicję poszczególnych sekcji. Poddano również krytyce sposób prezentacji informacji niezbędnych do ustalenia wyników z podstawowej działalności przedsiębiorstwa, konfrontując je $\mathrm{z}$ wersją poprzednią.

Krytyczne opinie dotyczące nowej formy prezentacji sprawozdania finansowego przedstawiły amerykańskie organizacje księgowe. Nowa forma prezentacji sprawozdań finansowych była szeroko analizowana i dyskutowana również przez biegłych rewidentów w Stanach Zjednoczonych (Shough 2009, s. 104-107). Uważali oni, że w pewnym stopniu zmiana formy prezentacji sprawozdania finansowego jest celowa, zgłosili jednak liczne uwagi krytyczne. Audytorzy nie uważali, że nowy sposób prezentacji zwiększy użyteczność przedstawianych danych, zatem decyzje podejmowane przez podmioty dostarczające kapitał 
przedsiębiorstwom nie będą bardziej efektywne. Biegli rewidenci byli bardzo podzieleni w kwestii rozdziału działalności gospodarczej i finansowej, a także wpływu tego podziału na użyteczność podejmowanych decyzji. Audytorzy byli zdania, że proponowane zmiany powinny dotyczyć głównie dużych spółek giełdowych, nie powinny być dedykowane dla podmiotów pozagiełdowych (Heino i Fontana 2011). Nie byli ponadto przekonani, czy metoda bezpośrednia sporządzania rachunku przepływów pieniężnych jest bardziej odpowiednia niż metoda pośrednia. Uważali z kolei, że działalność zaniechana powinna być wykazywana w osobnych sekcjach. Wątpliwości budzi również zdefiniowanie poszczególnych sekcji operacyjnej i inwestycyjnej (Gierusz 2010).

W opinii Komitetu ds. Polityki Sprawozdawczości Finansowej Amerykańskiego Stowarzyszenia Księgowych, Sekcja Rachunkowości Finansowej i Sprawozdawczości (The Financial Reporting Policy Committee of the Financial Accounting and Reporting Section of the American Accounting Association) zasadnicza zmiana układu i formy sprawozdania finansowego była bardzo potrzebna (Bradshaw i in. 2010). Analizując liczne badania naukowe, zauważono konieczność takiego przekazywania informacji księgowej, aby była czytelna i jasna dla wielu użytkowników sprawozdań finansowych. W opinii Komitetu projekt standardu poprawiał znacząco formę prezentacji sprawozdania finansowego, która byłaby w większym stopniu użyteczna dla inwestorów oraz kredytodawców. Podkreślono jednak wysokie koszty wdrożenia standardu oraz bardzo dużą jego złożoność. Również w opinii Komitetu Standardów Rachunkowości Finansowej Amerykańskiego Stowarzyszenia Księgowych (American Accounting Association's Financial Accounting Standards Committee) projekt standardu miał szanse poprawić użyteczność informacji finansowych prezentowanych w sprawozdaniu finansowym (Moehrle $\mathrm{i}$ in. 2010).

Według FASB wspólny projekt mógł przyczynić się do poprawy użyteczności sprawozdania finansowego w zakresie podejmowanych na jego podstawie decyzji. Należy jednak zwrócić uwagę na potencjalne problemy, które mogą utrudnić jego wdrożenie. Zaliczono do nich m.in. brak właściwych zapisów w założeniach koncepcyjnych i konieczność ich późniejszej zmiany, co nie zapewniałoby spójności założeń standardu. Trudności może powodować stosowanie dotychczasowych rozwiązań XBRL na potrzeby nowej wersji sprawozdawczości finansowej. Krytyce poddano również nazwę działalności gospodarczej, FASB proponował raczej nazwę „działalność operacyjna”. Operacje zaniechane powinny być prezentowane jako odrębna pozycja, niekoniecznie jako odrębna sekcja. Również cel dezagregacji wydaje się niejasny, brakuje w tej mierze bardziej zwięzłych i precyzyjnych wyjaśnien. Kontrowersyjna jest także klasyfikacja poszczególnych elementów w określonych sekcjach. Klasyfikacja aktywów i zobowiązań nie była do końca precyzyjna. Ponadto w Stanach Zjednoczonych sposób prezentowania 
informacji finansowej w sprawozdaniu finansowym jest w dużym stopniu zdeterminowany przynależnością do branży, stąd zmiana formy prezentacji może powodować trudności w praktyce gospodarczej (Cong 2008, Riedl i Srinivasan 2010)ํ․

Projekt powyższego standardu wydaje się śmiałą propozycją zmiany formy prezentacji sprawozdań finansowych. Pomysł ten nie doczekał się realizacji. Szeroka debata publiczna pokazuje jednak, że w społecznym przekonaniu forma prezentacji ma zasadnicze znaczenie dla użyteczności sprawozdań finansowych.

Poniżej autorzy przedstawili propozycję nowej formy prezentacji sprawozdania finansowego, która powinna zwiększać użyteczność prezentowanych informacji finansowych. Propozycja opiera się w części na opisanym powyżej projekcie oraz na wytycznych MSSF dotyczących wykazywania minimalnej liczby pozycji finansowych. W przpadku sprawozdania finansowego ogólnego przeznaczenia można wskazać pewne podstawowe problemy, które wynikają z tego, że jest ono sporządzone dla wielu użytkowników sprawozdań finansowych. Najbardziej użyteczna forma prezentacji sprawozdania finansowego może być zatem odmienna dla różnych jej odbiorców. Kwestia agregacji i dezagregacji pozycji również wydaje się trudna do rozwiązania. Zawsze będzie istniał problem właściwej agregacji pozycji, dla części użytkowników będzie ona wystarczająca, a dla niektórych nie. Przykładowo, inwestorzy indywidualni posiadają bardzo różnorodną wiedzę o sprawozdawczości finansowej czy funkcjonowaniu rynków kapitałowych. Zatem nawet w jednej grupie użytkowników sprawozdania finansowego preferencje w zakresie formatu i sposobu prezentacji danych mogą być różne. Należy ponadto zauważyć, że poszczególni odbiorcy informacji finansowej preferują różne metody wyceny, np. kredytodawcy - koszt historyczny, a inwestorzy - wartości rynkowe. Rozwiązaniem wymienionych problemów jest tworzenie interaktywnych sprawozdań finansowych, których forma może, ale nie musi być tworzona przez użytkowników sprawozdawczości finansowej. Dużym atutem interaktywnych sprawozdań finansowych jest możliwość doboru formy i zakresu reprezentowanych informacji w zależności od indywidulanych potrzeb poszczególnych odbiorców informacji finansowej. Poprzez użycie funkcji agregacja/dezagregacja (A/D) użytkownik będzie mógł sam określić żądany przez siebie poziom szczegółowości, może być on odmienny w poszczególnych sekcjach czy pozycjach finansowych. Przykładowo, pozycję ,środki trwałe” można dezagregować na budynki, urządzenia techniczne i maszyny, lub jeszcze niżej, czy wręcz zapoznać się z najbardziej wartościowymi środkami trwałymi w przedsiębiorstwie. Z kolei przycisk „?” oznacza notę do danej pozycji finansowej, czy też kluczowe informacje na temat

\footnotetext{
${ }^{1}$ Podobne, niejednoznaczne stanowisko przedstawił również Departament Rachunkowości Ministerstwa Finansów w zakresie oceny nowej formy prezentacji sprawozdania finansowego (Prezentacja sprawozdań finansowych... 2010, s. 1).
} 
Tabela 1. Nowa forma prezentacji sprawozdania finansowego w kontekście jego użyteczności

\begin{tabular}{|c|c|}
\hline Sprawozdanie z sytuacji finansowej & Sprawozdanie z całkowitych dochodów \\
\hline Działalność operacyjna & Działalność gospodarcza \\
\hline $\begin{array}{l}\text { a. Aktywa i zobowiązania operacyjne A/D; ? } \\
\text { - wartości niematerialne A/D; ? } \\
\text { - srodki trwałe A/D; ? } \\
\text { - zapasy A/D; ? } \\
\text { - należności krótkoterminowe A/D; ? } \\
\text { - gotówka A/D; ? } \\
\text { - zobowiązania handlowe A/D; ? } \\
\text { - zobowiązania z tytułu wynagrodzeń A/D; ? } \\
\text { b. Aktywa i zobowiązania inwestycyjne A/D; ? } \\
\text { - inwestycje krótkoterminowe A/D; ? } \\
\text { - inwestycje długoterminowe A/D; ? }\end{array}$ & $\begin{array}{l}\text { a. Przychody i koszty operacyjne A/D; ? } \\
\text { - przychody ze sprzedaży A/D; ? } \\
\text { - koszt sprzedanych produktów, usług A/D; ? } \\
\text { - koszty sprzedaży A/D; ? } \\
\text { - koszty ogólne i administracyjne A/D; ? } \\
\text { - pozostałe przychody, koszty operacyjne } \\
\text { A/D; ? } \\
\text { b. Przychody i koszty inwestycyjne A/D; ? } \\
\text { - przychody z tytułu dywidend i odsetek } \\
\text { A/D; ? } \\
\text { - udział zysków w jednostkach stowarzy- } \\
\text { szonych A/D; ? } \\
\text { - zmiany wartości godziwej w inwestycjach } \\
\text { kapitałowych A/D;? } \\
\text { - zmiany wartości godziwej w aktywach } \\
\text { finansowych A/D; ? }\end{array}$ \\
\hline Działalność finansująca & Działalność finansująca \\
\hline $\begin{array}{l}\text { a. Aktywa finansujące A/D; ? } \\
\text { - kapitał podstawowy A/D; ? } \\
\text { - kapitał zapasowy A/D; ? } \\
\text { - zyski zatrzymane A/D; ? } \\
\text { - wynik finansowy netto A/D; ? } \\
\text { b. Zobowiązania finansujące A/D; ? } \\
\text { - zadłużenie długoterminowe A/D; ? } \\
\text { - zadłużenie krótkoterminowe A/D; ? }\end{array}$ & $\begin{array}{l}\text { Przychody, koszty z tytułu działalności finan- } \\
\text { sującej A/D; ? } \\
\quad \text { - odsetki od zadłużenia A/D; ? }\end{array}$ \\
\hline $\begin{array}{l}\text { Podatek dochodowy A/D; ? } \\
\text { - krótkoterminowe zobowiązania podat- } \\
\text { kowe A/D; ? } \\
\text { - aktywa z tytułu odroczonego podatku } \\
\text { A/D;? }\end{array}$ & $\begin{array}{l}\text { Podatek dochodowy z działalności kontynu- } \\
\text { owanej (gospodarczej i finansującej) A/D; ? }\end{array}$ \\
\hline $\begin{array}{l}\text { Działalność zaniechana A/D; ? } \\
\text { — aktywa z tytułu działalności zaniechanej } \\
\text { A/D; ? } \\
\text { - zobowiązania z tytułu działalności zanie- } \\
\text { chanej A/D; ? }\end{array}$ & $\begin{array}{l}\text { Działalność zaniechana po uwzględnieniu } \\
\text { podatku dochodowego A/D; ? } \\
\text { - zyski i straty z działalności zaniechanej } \\
\text { A/D;? }\end{array}$ \\
\hline- & $\begin{array}{l}\text { Inne całkowite dochody po uwzględnieniu } \\
\text { podatku dochodowego A/D;? }\end{array}$ \\
\hline $\begin{array}{l}\text { Sekcja transakcji dotyczących wielu kategorii } \\
\text { A/D;? }\end{array}$ & $\begin{array}{l}\text { Sekcja transakcji dotyczących wielu kategorii } \\
\text { A/D;? }\end{array}$ \\
\hline
\end{tabular}

Źródło: opracowanie własne na podstawie (Staff Draft Implementation..., 2010, s. 21-23). 
tej pozycji, np. procentowy rozkład przychodów w poszczególnych krajach. Wzór uproszczonego sprawozdania przedstawiono w tabeli 1.

Technologią, która mogłaby wydatnie wspomóc interaktywny sposób prezentacji sprawozdania finansowego, jest technologia XBRL, w której każda pozycja sprawozdawcza jest oznaczana za pomocą określonego oznakowania, czyli tzw. tagów. Obecnie są tworzone tzw. taksonomie XBRL, które stanowią zestaw tagów oraz wzajemnych relacji pomiędzy nimi, tworząc w ten sposób pożądane przez użytkowników struktury informacji.

\section{Podsumowanie}

W badaniach empirycznych rachunkowości forma prezentacji jest zazwyczaj ograniczana do bilansu i rachunku wyników, rzadziej do sprawozdania z przepływów pieniężnych i zestawienia zmian w kapitale własnym. Zasadniczo w przypadku badań empirycznych nie można mówić o formie prezentacji informacji dodatkowej, tutaj badania dotyczą zakresu ujawnianej informacji.

Analiza regulacji prawnych sprawozdawczości finansowej, projektów standardu nowej formy prezentacji oraz wybranych badań empirycznych dostarcza argumentów wskazujących, że forma prezentacji może mieć wpływ na proces odbioru i przetwarzania informacji przez użytkowników sprawozdań finansowych. W rezultacie autorzy opracowania dochodzą do wniosku, że forma prezentacji sprawozdania finansowego może wpływać na jakość sprawozdań finansowych oraz decyzje podejmowane przez inwestorów. Jasny i klarowny sposób przekazu może zwiększyć poziom zrozumienia treści prezentowanych w sprawozdaniu finansowym. Do podstawowych aspektów formy prezentacji należy zaliczyć miejsce prezentacji danej pozycji w sprawozdaniu finansowym, poziom jej agregacji, formę prezentacji oraz spójność poszczególnych części sprawozdania finansowego.

Obecne regulacje prawne dotyczące formy prezentacji budzą liczne zastrzeżenia, zwłaszcza w zakresie spójności poszczególnych części sprawozdania finansowego. Nie są one ze sobą logicznie powiązane, co negatywnie odbija się na analizie treści sprawozdania finansowego, zwłaszcza przez niedoświadczonych użytkowników. Przedstawiony w artykule projekt standardu dotyczący nowej formy prezentacji, który ostatecznie nie został przyjęty do stosowania przez IASB i FASB, prezentuje interesującą koncepcję sprawozdawczości finansowej, która przynajmniej częściowo rozwiązywałaby wskazane problemy. Zdaniem autorów należy rozważyć powrót do tej koncepcji w sprawozdawczości finansowej na gruncie teorii rachunkowości, jak również na poziomie stanowienia standardów krajowych lub międzynarodowych. Według autorów perspektywicznym sposobem 
zwiększenia użyteczności danych finansowych jest możliwość sporządzenia interaktywnego sprawozdania finansowego.

\section{Literatura}

Acton D. (2009), Am Explanation of Financial Analysis Using The FASB's Preliminary Views on Financial Statement Presentation, ,Journal of Business \& Economics Research", vol. 7, nr 10, https://doi.org/10.19030/jber.v7i10.2348.

Ahmed A.S., Kilic E., Lobo G.J. (2006), Does Recognition versus Disclosure Matter? Evidence from Value Relevance of Banks' Recognized and Disclosed Derivative Financial Instruments, „The Accounting Review”, vol. 81, https://doi.org/10.2308/ accr.2006.81.3.567.

Andrzejewski M., Maślanka T. (2016), An Informative Function of Cash Flow Accounts on an Example of the Listed Companies in the Construction Branch (w:) Medzinarodna vedecka konferencia „Rozvoj Euroregionu Beskydy IX” spolecensko-ekonomicke podmienky v regionoch $v$ novom programovom obdobi EU: ekonomika - manazment - bezpecnost, red. J. Stofkova, Zilinska Univerzita v Zilinia.

Barth M., Clinch G., Shibano T. (2003), Market Effects of Recognition and Disclosure, ,Journal of Accounting Research”, vol. 41, nr 4, https://doi.org/10.1111/1475679x.00117.

Bek-Gaik B. (2013), Sprawozdawczy wymiar rachunku wyników w warunkach globalnego rynku, Wydawnictwo Uniwersytetu Łódzkiego, Łódź.

Bradshaw M., Callahan C., Ciesielski J., Gordon E., Kohlbeck M., Hodder L., Hopkins P.E., Laux R., McVay S., Stober T., Stocken P., Yohn T.Y. (2010), The American Accounting Association's Financial Reporting Policy Committee's Response to the Preliminary Views on Financial Statement Presentation, „Accounting Horizons”, vol. 24, nr 2, https://doi.org/10.2308/acch.2010.24.2.279.

Bratten B., Choudhary P., Schipper K. (2013), Evidence That Market Participants Assess Recognized and Disclosed Items Similarly when Reliability is Not an Issue, „The Accounting Review”, vol. 88, nr 4, https://doi.org/10.2308/accr-50421.

Buk H. (2011), Sprawozdanie z całkowitych dochodów w świetle koncepcji zachowania kapitału (w:) Sprawozdawczość i rewizja finansowa - kierunki zmian, red. B. Micherda, Wydawnictwo Uniwersytetu Ekonomicznego w Krakowie, Kraków.

Cain A. (2008), IASB and FASB Propose New Objectives for Financial Statement Presentation, „Internal Auditor”, December.

Choi B., Collins D., Johnson W.B. (1997), Valuation Implications of Reliability Differences: The Case of Nonpension Postretirement Benefit Obligation, „The Accounting Review", vol. 72, nr 3.

Choudhary P. (2011), Evidence on Differences between Recognition and Disclosure: A Comparison of Inputs to Estimate Fair Values of Employee Stock Options, „Journal of Accounting and Economics”, vol. 51, nr 1-2, https://doi.org/10.1016/j.jacceco.2010.09.004.

Cong Y. (2008), Relationship between Industry Characteristics of Firms and Their Financial Statement Presentation Formats: An Empirical Study in the United States, „International Journal of Management”, vol. 25, nr 1. 
Czubakowska K. (1989), Kierunki przeobrażeń rachunku wyników, „Zeszyty Naukowe Akademii Ekonomicznej w Katowicach", nr 1.

Davis-Friday P.Y., Folami L.B., Liu C.S., Mittelstaedt H.F. (1999), The Value Relevance of Financial Statement Recognition versus Disclosure: Evidence from SFAS No. 106, „The Accounting Review”, vol. 74, nr 4.

Davis-Friday P.Y., Liu C., Mittelstaedt H.F. (2004), Recognition and Disclosure Reliability: Evidence from SFAS No. 106, „Contemporary Accounting Research”, vol. 21, nr 2, https://doi.org/10.1506/t0vc-q15y-w5qv-4ukq.

DiFabio Ch. (2009), Extreme Makeover for Financial Statements, „Financial Executive”, April.

Giacomino D.E., Akers M.D. (2010), Proposed Financial Statement Changes: Reactions to the FASB-IASB Discussion Paper, ,Journal of Business \& Economics Research”, vol. 8, nr 7, https://doi.org/10.19030/jber.v8i7.743.

Gierusz J. (2005), Koszty i przychody w świetle nadrzędnych zasad rachunkowości, ODDK, Gdańsk.

Gierusz J. (2010), Ocena przygotowanego przez IASB i FASB projektu sprawozdania finansowego, ,Zeszyty Teoretyczne Rachunkowości”, vol. 56, nr 112.

Goncharov I., Hodgson A. (2011), Measuring and Reporting Income in Europe, ,Journal of International Accounting Research", vol. 10, nr 1, https://doi.org/10.2308/jiar.2011.10.1.27.

Grabiński K. (2012), Sprawozdanie z zysku całkowitego a bieżq̨cy zysk operacyjny - użyteczność decyzyjna w świetle badań naukowych, „Zeszyty Teoretyczne Rachunkowości”, vol. 66, nr 122.

Grabiński K., Kędzior M. (2007), Bilanse według ustawy o rachunkowości i Międzynarodowych Standardów Rachunkowości, „Rachunkowość”, vol. 11.

Grabiński K., Kędzior M., Krasodomska J. (2014), Współczesna rachunkowość na rynkach kapitałowych, Difin, Warszawa.

Górska A., Parkitna A. (2010), Propozycja modyfikacji wariantu porównawczego rachunku zysków i strat w zakresie pozycji zrównanych z przychodami, ,Zeszyty Teoretyczne Rachunkowości”, vol. 57, nr 113.

Heino H., Fontana A. (2011), Analyzing Financial Statements after Converging International Financial Reporting Standards and Us Financial Accounting Standards for Publicly Traded Companies in the USA, ,Academy of Accounting \& Financial Studies Journal", vol. 15, nr 2.

Henry E., Holzmann O.J. (2008), Financial Statement Presentation, ,The Journal of Corporate Accounting \& Finance", November/December, https://doi.org/10.1002/ jcaf.20455.

Hirst D.E., Hopkins P.E. (1998), Comprehensive Income Reporting and Analysts' Valuation Judgments, ,,Journal of Accounting Research”, vol. 36, https://doi.org/10.2307/2491306.

Klimczak K.M. (2011), Market Reaction to Mandatory IFRS Adoption: Evidence from Poland, ,Accounting and Management Information Systems”, vol. 10, nr 2.

Lennard A. (2007), Stewardship and the Objectives of Financial Statements: A Comment on IASB's Preliminary Views on an Improved Conceptual Framework for Financial Reporting: The Objective of Financial Reporting and Qualitative Characteristics of Decision-Useful Financial Reporting Information, „Accounting in Europe”, vol. 4, nr 1, https://doi.org/10.1080/17449480701308774. 
Lev B. (1968), The Aggregation Problem in Financial Statements: An Informational Approach, „Journal of Accounting Research”, vol. 6, nr 2, https://doi.org/10.2307/ 2490239.

Luty Z. (2010), Kierunki zmian sprawozdawczości finansowej, „Zeszyty Teoretyczne Rachunkowości”, vol. 56, nr 112.

Łazarowicz E. (2016), Dyskusja wokót celu sprawozdawczości finansowej opartej na Międzynarodowych Standardach Sprawozdawczości Finansowej, „Zeszyty Teoretyczne Rachunkowości”, vol. 87, nr 143.

Masztalerz M. (2010), Użyteczność sprawozdań finansowych dla inwestorów giełdowych w świetle finansów klasycznych i behawioralnych, ,Zeszyty Teoretyczne Rachunkowości", vol. 57, nr 113.

Maślanka T. (2004), Rachunek przepływów pieniężnych jako źródło informacji o przedsiębiorstwie (w:) Nauki finansowe wobec współczesnych problemów gospodarki polskiej, red. Z. Dresler, Akademia Ekonomiczna w Krakowie, Kraków.

McClain G., McLelland A.J. (2008), Shaking Up Financial Statement Presentation. An Early Look at the FASB and IASB Financial Statement Project, ,Journal of Accountancy", November.

Międzynarodowe Standardy Sprawozdawczości Finansowej (2011), International Accounting Standard Board, IFRS Foundation, London.

Moehrle S., Stober T., Jamal K., Bloomfield R., Christensen T.E., Colson R.H., Ohlson J., Penman S., Sunder S., Watts R.L. (2010), Response to the Financial Accounting Standards Board's and the International Accounting Standard Board's Joint Discussion Paper Entitled Preliminary Views on Financial Statement Presentation, „Accounting Horizons", vol. 24, nr 1, https://doi.org/10.2308/acch.2010.24.1.149.

Oliver K. (2014), Balance Sheet Presentation under IAS 1 and US GAAP, Grand Valley State University, https://scholarworks.gvsu.edu/cgi/viewcontent.cgi?article=1336\&context=honorsprojects (data dostępu: styczeń 2018).

Pacter, P. (2013), What Have IASB and FASB Convergence Efforts Achieved?, ,Journal of Accountancy", vol. 215, nr 2.

Pounder B. (2008), Financial Statements Unlike Any You've Seen, „Strategic Finance”, November.

Prezentacja sprawozdań finansowych - ocena EFRAG (2010), materiały konferencji nt. „Prezentacja sprawozdań finansowych” (Warszawa, 26 listopada 2010 r.), IASB, Komitet Standardów Rachunkowości, Ministerstwo Finansów, Warszawa.

Ragland L., Reck J.L. (2016), The Effects of the Method Used to Present A Complex Item on the Face of a Financial Statement on Nonprofessional Investors' Judgments, „Advances in Accounting, Incorporating Advances in International Accounting”, vol. 34, https://doi.org/10.1016/j.adiac.2016.07.006.

Riedl E., Srinivasan S. (2010), Signaling Firm Performance through Financial Statement Presentation: An Analysis Using Special Items, „Contemporary Accounting Research", vol. 27, nr 1, https://doi.org/10.1111/j.1911-3846.2010.01009.x.

Rivera A.R.L. i in. (2014), IASB and FASB Convergence Project: Where Are They Now? (w:) Global Conference on Business \& Finance Proceedings, vol. 9, nr 1, Institute for Business \& Finance Research.

Staff Draft Implementation Guidance (2010), IASB, 1 July, London. 
Shough S. (2009), What the CPA's Think about the Proposed Financial Statement Presentation, ,Journal of Business \& Economics Research”, vol. 7, nr 11, https://doi.org/ 10.19030/jber.v7i11.2359.

Walińska E. (2009), Bilans jako fundament sprawozdawczości finansowej, Oficyna Wydawnicza Wolters Kluwer Business, Warszawa.

Walińska E. (2010), Bilans - propozycje nowej formuły sprawozdawczej, „Zeszyty Teoretyczne Rachunkowosci", vol. 56, nr 112.

Ward S.P., Ward D.R. (2013), A Proposed New Vision for Financial Statements: A Primer for Non-Financial Executives, „,Business Studies Journal”, vol. 5, nr 1.

Ward S.P., Ward D.R., Deck A.B. (2012), Financial Statement Presentation: A Sneak Peak at the Proposed Format, ,Journal of Business and Accounting”, vol. 5, nr 1.

Wiedman C., Wier H. (2004), The Market Value Implications of Post-retirement Benefit Plans and Plan Surpluses - Canadian Evidence, ,Canadian Journal of Administrative Sciences", vol. 21, https://doi.org/10.1111/j.1936-4490.2004.tb00338.x.

Winiarska K. (1994), Rachunek kosztów $i$ wyników w zarzqdzaniu jednostkami gospodarczymi, „Rozprawy i Studia Uniwersytetu Szczecińskiego”, t. (CCXXXIX) 165, Wydawnictwo Naukowe Uniwersytetu Szczecińskiego, Szczecin.

Wójtowicz P. (2009), Czy wynik całościowy jest potrzebny rynkowi kapitałowemu? (w:) Rachunkowość w procesie tworzenia wartości przedsiębiorstwa, red. I. Sobańska, T. Wnuk-Pel, Wydawnictwo Uniwersytetu Łódzkiego, Łódź.

Wójtowicz, T. (2015), Aspekty praktyczne użyteczności sprawozdań finansowych, „Zeszyty Teoretyczne Rachunkowości”, vol. 82, nr 138, https://doi.org/10.5604/ 16414381.1155823 .

Zasiewska K. (2011), Koncepcja podatkowego rachunku zysków i strat. Artykuł dyskusyjny, „Zeszyty Teoretyczne Rachunkowości”, vol. 64, nr 12.

\section{How Information Is Presented in Financial Reports and the Usefulness of the Forms Chosen - a Review of Selected Research}

(Abstract)

The purpose of the research was to gather and present arguments available in the subject literature which support the thesis that how financial statements are presented impacts their usefulness. The basic research method was an analysis of Polish and international literature on the subject, with the article then summarising the results of empirical studies done by other authors. In the majority of cases the problem was analysed in the context of financial statements prepared under the Polish Accounting Act, IAS/IFRS and US GAAP. The first issue addressed is the aggregation and disaggregation of items reported in financial statements. The study also examines the presentation of financial statements prepared by IASB and FASB. The analysis of the literature and the studies presented together show that the form in which financial statements are presented has a profound impact on their usefulness.

Keywords: usefulness of financial statements, the form in which financial statements are presented, aggregation and disaggregation of financial elements, conceptual framework of financial reporting. 